\title{
Concentrate reduction and sequential roughage offer to dairy cows: effects on milk protein yield, protein efficiency and milk quality
}

\author{
Florian Leiber*, Katharina Dorn, Johanna K. Probst, Anne Isensee, Nick Ackermann, Anton Kuhn \\ and Anet Spengler Neff
}

Departement of Livestock Science, Research Institute of Organic Agriculture (FiBL), Ackerstrasse 113, CH-5070 Frick, Switzerland

Received 11 December 2014; accepted for publication 20 January 2015; first published online 16 April 2015

\begin{abstract}
An experiment was conducted during 6 weeks to evaluate effects of a reduced dietary level of protein-rich concentrates in a moderate dairy production system on cows' performance, protein efficiency and milk quality including fatty acid profiles. Twenty-three lactating cows (Swiss Fleckvieh) were assigned either to a group receiving on average $2.4 \mathrm{~kg} / \mathrm{d}$ individually fed concentrates (Prot,$+ n$ $=12$ ) or to a group receiving no individually fed concentrates (Prot-, $n=11$ ). All cows had adlibitum access to a total mixed ration (TMR) mainly based on grass and maize silage, hay and little potatoes and soybean cake. In weeks $4-6$ of the experiment, part of the hay was excluded from the TMR, and fed separately in the morning. Individual feed intake and milk yield were recorded during weeks 3 and 6 of the experiment; at the same time feed, faeces and milk samples were collected twice per week for analyses. Data were processed in linear mixed models. Omission of individual concentrates in Prot- was fully compensated by higher roughage intake in terms of dry matter. Crude protein (CP) and net energy intake was almost maintained. Despite a lower apparent CP digestibility in Prot-, the ratio of milk protein to ingested CP was the same in both groups, indicating a higher ruminal utilisation of degraded CP in Prot-. This corresponded with lower milk urea concentrations in Prot-. Milk quality was affected in terms of lower concentrations of linoleic and conjugated linoleic acid in milk fat of Prot-. Concentrations of oddand branched-chain fatty acids in milk were increased in Prot-. Sequential offer of hay and TMR did not lead to considerable effects in intake, efficiency and milk quality. In conclusion, the results indicate that the efficiency of feed protein utilisation for milk protein is not impaired if concentrates are reduced in a moderate- to low-input dairy production system.
\end{abstract}

Keywords: Feeding system, feeding sequence, forage, protein efficiency, feed conversion.

In Europe, large amounts of concentrates as sources of easily degradable carbohydrates and proteins are fed to cattle in beef and dairy production systems in order to achieve high productivity per animal. This results in high-input highoutput systems requiring a large surface of arable land in Europe and overseas which could be alternatively used for production of directly edible human food (Cassidy et al. 2013). The concentrate feedstuffs for ruminants increase the production pressure on global arable land if they are not real by-products of other industries. Focusing on the animal, it appears that feeding concepts with high dietary concentrate levels neglect the basic ability of the ruminant to convert fibre-rich grass-swards efficiently (Knaus, 2009; Clauss et al. 2010). These considerations justify the differentiation between the conversion of feedstuffs which are edible

\footnotetext{
*For correspondence; e-mail: florian.leiber@fibl.org
}

for humans and of those which are not (Wilkinson, 2011; O'Mara, 2012). In this perspective, ruminant production gains a higher productivity compared with production with monogastric animals if it is grass-based because it competes less for food directly edible by humans (Wilkinson, 2011; O'Mara, 2012). In roughage-only dairy feeding systems the amount of milk produced per unit of forage can be significantly higher than in systems supplementing concentrates (Ertl et al. 2014). Against the background of globally limited resources and growing demands for food production (Pelletier \& Tyedmers, 2010) this appears a strong reason to develop dairy production systems which are based less on concentrates than is common. Reducing the protein supplements is of particular interest, because of the ecological and social side-effects of global soybean production (von Witzke et al. 2011).

Concerns may be raised regarding the physiological need for high nutrient concentrations in high-yielding 
cows (Gross et al. 2011). In less intensive systems with cattle breeds which represent rather dual-purpose types it might be easier to reduce concentrates in dairy production, because these breeds are expected to be more adaptable to lower nutrient density (Knaus, 2009; Ivemeyer et al. 2014). Recent results from semi-intensive production systems in Switzerland and Austria show that reducing or omitting concentrates is possible without impairing animal health and fertility (Horn et al. 2014; Ertl et al. 2014; Ivemeyer et al. 2014). Feeding less easily degradable protein might even bring a metabolic advantage, since in the rumen less ammonia is produced, which has to be detoxified by the cow's metabolism, limiting endogenous amino acid availability (Parker et al. 1995).

Recent experiences in Switzerland show that feeding concentrates lower in $\mathrm{CP}$ than recommended by the national feeding recommendations (Agroscope, 2013) does not reduce the milk protein yield as much as calculated (Furger et al. 2013; Ivemeyer et al. 2014). This indicates that the protein efficiency of the dairy cow might be higher than assumed in the equations of the national recommendation frameworks (Leiber, 2014). Several recent studies show that the protein efficiency (ratio of milk protein to feed protein) increases as dietary protein concentration decreases (Kälber et al. 2012; Staerfl et al. 2012; Cantalapiedra-Hijar et al. 2014). This might be partly a result of lower $\mathrm{N}$ - and amino acid losses during ammonia production and detoxification (Parker et al. 1995) but also of increased urea recycling to the rumen, which can amount to more than $50 \%$ of the total $\mathrm{N}$ intake (Røjen et al. 2008). Further, decreasing dietary CP should result in lower $\mathrm{N}$ losses via urinary and milk urea (Spek et al. 2013). Therefore, it might be expected that the $\mathrm{N}$-conversion efficiency from feed to milk would rise if protein concentrates are restricted or omitted and roughage quality remains good. However, the available data are still scarce and more experimental and practice-based data on protein efficiency in low-concentrate feeding systems are needed.

Since roughage-only diets may be less dense in nutrients, a high feed intake of the animals becomes more important. This should be subject of breeding goals for cows adapted to such feeding regimes, but also feed quality and the feeding techniques and sequences are of relevance in this context (Macleod et al. 1994; Lyman et al. 2011). One factor triggering intake could be the diversity of the feed offered. Feeding different roughages separately and not just in a mixture might influence ruminants' appetite (Villalba et al. 2004; Lyman et al. 2011) but data concerning sequential feeding of roughages differing in nutrient composition, conservation type and taste are apparently lacking.

Milk quality may be significantly affected by feeding strategies. Forage-concentrate proportions and the origin of roughages affect the concentration of value-giving n-3 fatty acids (FA) and conjugated linoleic acids in milk fat (Khiaosa-ard et al. 2010; Shingfield et al. 2013). Also, FA profiles may be indicative of shifts in rumen fermentation
(Fievez et al. 2012; Shingfield et al. 2013) and thus be used for the evaluation of feeding situations.

Against the background of the mentioned aspects, the aim of the study presented here was (i) to evaluate the effects of reducing protein concentrates on feed intake, animal performance, protein efficiency and milk quality in a dairy system with a moderate milk type cow breed in order to contribute controlled experimental data for low-concentrate dairy production systems, and (ii) to assess whether or not a partial disintegration of a mixed ration and sequential feeding of the roughages has any influences on feed intake and performance.

\section{Materials and methods}

\section{Experimental protocol}

In a dairy herd of an organic farm in Switzerland (Münsingen, Berne), 24 cows (Swiss Fleckvieh) were assigned to two different experimental groups, group Prot+ and group Prot-. One cow in group Prot- had to be excluded owing to data losses in intake recording. Groups were balanced for milk yield, milk protein concentration and days in milk. The respective averages for Prot+ and Prot- were: milk yield, $26 \cdot 1 \pm 5.4$ and $24.5 \pm 6.6 \mathrm{~kg} / \mathrm{d}$; milk protein concentration $3 \cdot 15 \pm 0 \cdot 22$ and $3 \cdot 30 \pm 0 \cdot 42 \mathrm{~g} /$ $100 \mathrm{~g}$ milk; and $89 \pm 78$ and $113 \pm 78 \mathrm{~d}$ in milk. Four cows of Prot+ and two cows of Prot- were primiparous. The experiment was carried out in January, February and March 2014. Cows were kept in a stanchion barn with separated feeding places, which allowed individual feeding and weighing of the roughages and residuals. They had access to a farmyard outside the barn for $1 \mathrm{~h}$ every second day. They were milked twice daily at 6.00 and at 17·00. The animal trial was approved by the veterinary authorities (approval No. 75656; Veterinäramt Aargau).

Before the experiment started, all cows were fed with a TMR, composed of dry matter (DM) proportions of $0 \cdot 3$ maize silage, 0.32 grass silage, 0.21 hay, 0.09 dried alfalfa meal, 0.05 potatoes and 0.03 soybean cake. The nutrient concentrations are shown in Table 1. The TMR was always available ad libitum, being freshly offered several times between 6.00 and $8 \cdot 00,10.00$ and $12.00,16.00$ and 18.00, and at 19.00. The cows were individually supplemented with two concentrates, according to milk yield (nutrient concentrations and components see Table 1); provided during the milking time. All cows had ad-libitum access to water at any time.

During Period 1, the supplementary concentrates of group Prot- were reduced to zero within $3 \mathrm{~d}$. From then on, group Prot- received no more individual supplementary concentrates during the whole experiment. However they still received the soybean cake which was part of the TMR. Group Prot+ received always the same concentrate amounts as initially (concentrate 1: $1 \cdot 45 \pm 0 \cdot 66 \mathrm{~kg}$ DM; concentrate $2: 0 \cdot 98 \pm 0 \cdot 26 \mathrm{~kg}$ DM). Period 1 lasted for $21 \mathrm{~d}$ with the last $4 \mathrm{~d}$ serving for sample and data collection. Until and 
Table 1. Nutrient concentrations in the feedstuffs used

\begin{tabular}{|c|c|c|c|c|c|c|c|c|}
\hline & \multicolumn{2}{|l|}{ TMR1 } & \multicolumn{2}{|l|}{ TMR2 } & \multicolumn{2}{|l|}{ Hay } & \multirow[b]{2}{*}{ Concentrate $1 \dagger$} & \multirow[b]{2}{*}{ Concentrate 2} \\
\hline & Average & SD & Average & SD & Average & SD & & \\
\hline Crude protein (g/kg DM) & 140 & $\pm 4 \cdot 5$ & 133 & $\pm 3 \cdot 0$ & 172 & $\pm 13 \cdot 0$ & 250 & 380 \\
\hline Acid detergent fibre (g/kg DM) & 298 & \pm 30 & 293 & $\pm 0 \cdot 0$ & 335 & $\pm 20 \cdot 5$ & $80 \cdot 7$ & $77 \cdot 2$ \\
\hline Lignin $(g / k g$ DM) & $41 \cdot 9$ & $\pm 0 \cdot 65$ & $38 \cdot 9$ & $\pm 1 \cdot 35$ & $48 \cdot 0$ & $\pm 6 \cdot 45$ & $2 \cdot 7$ & $2 \cdot 5$ \\
\hline Crude ash (g/kg DM) & $91 \cdot 6$ & $\pm 0 \cdot 05$ & $85 \cdot 8$ & $\pm 0 \cdot 10$ & $90 \cdot 2$ & \pm 0.95 & 70 & 95 \\
\hline $\mathrm{NEL}(\mathrm{MJ} / \mathrm{kg})$ & $5 \cdot 65$ & $\pm 0 \cdot 05$ & $5 \cdot 70$ & $\pm 0 \cdot 00$ & $5 \cdot 40$ & $\pm 0 \cdot 30$ & $7 \cdot 5$ & $7 \cdot 0$ \\
\hline
\end{tabular}

†Concentrate 1 (No 1064, Lehmann Biofutter, Gossau, Switzerland) based on soybean cake, wheat, barley, rapeseed cake, corn, and sunflower cake. ‡Concentrate 2 (No 1078, Lehmann Biofutter, Gossau, Switzerland) based on soybean cake, rapeseed cake, and sunflower cake.

during Period 1 all cows received the TMR1, which was the same as fed before. Subsequently to the sample collection days of Period 1, Period 2 started. The concentrate allocation to both groups remained the same, but TMR1 was replaced by TMR2 (composed of DM proportions of 0.35 maize silage, 0.38 grass silage, 0.06 hay, 0.11 dried alfalfa meal, 0.06 potatoes and 0.04 soybean cake; nutrient concentrations see Table 1) for both groups, meaning that part of the hay was not included in the TMR anymore. In lieu thereof, in the time between 6.00 and 8.00 , all cows received high-quality hay ad libitum, instead of $T M R$, during the whole Period 2, which also lasted for $21 \mathrm{~d}$ with the last $4 \mathrm{~d}$ serving for sample and data collection.

During the respective four collection days of both periods, daily feed intake was completely recorded for each individual cow by hand weighing of the feed offered and the refusals. Milk yield was recorded and individual milk samples were drawn in the evening of day 1 and the morning of day 2, the evening of day 3 and the morning of day 4. Evening and subsequent morning samples were aliquotely mixed and stabilised with Bronopol ${ }^{\circledR}$ for analysis. A second aliquot of the milk samples was frozen for later FA analysis. Individual faecal samples were taken from the rectum in the afternoon of the respective days 2 and 4 of each collection period. Feed samples of all roughages were drawn at days 1 and 3. Faeces and forage samples were dried immediately after collection at $60^{\circ} \mathrm{C}$ for $48 \mathrm{~h}$ and subsequently ground through a $1 \cdot 0-\mathrm{mm}$ sieve for analysis.

\section{Analyses}

Forage and faeces samples were analysed by near infrared spectroscopy with regression equations for organic matter, crude ash, CP, neutral detergent fibre (NDF), acid detergent fibre (ADF), lignin, and net energy for lactation (NEL) with a FOSS 5000 (Foss, Eden Prairie MN, USA) by and according to the methods of Cumberland Valley Analytical Services, Maugansville MD, USA (CVAS, 2008). Bronopol stabilised milk samples were analysed by medium infrared spectroscopy (MilkoScan 4000, Foss Electric, Hillerød, Denmark) with regression equations for protein, fat and urea. Milk FA were analysed after thawing the frozen samples. Transesterification to fatty acid methyl esters
(FAME) was done following the method for cold base-catalysed transesterification provided by Suter et al. (1997). Subsequently, FAME were analysed on a GC (6890N, Agilent Technologies Inc., Santa Clara CA, USA) equipped with a Supelcowax ${ }^{\mathrm{TM}} 10$ column $(60 \mathrm{~m}$, Supelco, Bellefonte PA, USA) and a MS detector (5973, Agilent Technologies Inc.). Carrier gas was He. Injection was $3 \mu \mathrm{l}$ with a split ratio of 1:5. Oven temperature settings were: $50{ }^{\circ} \mathrm{C}$ for $1 \mathrm{~min}$, increase of $15 \mathrm{deg} / \mathrm{min}$ up to $200{ }^{\circ} \mathrm{C}$, increase of $3 \mathrm{deg} / \mathrm{min}$ up to $230{ }^{\circ} \mathrm{C}$, isothermal for $50 \mathrm{~min}$.

\section{Data calculations and analysis}

Apparent protein digestibility was estimated based on the assumption that lignin would be totally indigestible. The equations for the estimation were:

Digestibility $_{\text {prot }}=1-\left(\operatorname{protein}_{\text {faecal amount }} / \operatorname{protein}_{\text {intakeamount }}\right)$

Protein $_{\text {faecalamount }}=$ faecal amount $[\mathrm{gDM} / \mathrm{d}] \times$ faecalCP $[\mathrm{g} / \mathrm{kgDM}]$

Faecal amount $[\mathrm{gDM} / \mathrm{d}]=\operatorname{lignin}_{\text {intake }}[\mathrm{g} / \mathrm{d}] / \operatorname{lignin}_{\text {faecal conc }}[\mathrm{g}$ lignin $/ \mathrm{kg}$ faeces $]$

Protein efficiency was calculated as the ratio of milk protein secretion to CP intake.

Data were analysed in a linear mixed model considering group and period as fixed effects and cow as random effect. The interaction of group and period was also included in the model. Where applicable (milk and protein yields as well as milk composition), baseline values, recorded 1 week before the experiment started, were included in the model as covariates with 'variance components'. Normality of random effects was verified. Data were processed with the statistical software SPSS ${ }^{\circledR}$ V21.

\section{Results}

Omission of individually fed concentrates led to a significantly increased intake of TMR in group Prot- during the whole experiment (Table 2). This compensated the DM intake from concentrates by almost $100 \%$, if compared with group Prot+. Crude protein intake was numerically lower in Prot- but neither CP intake nor NEL intake were 
Table 2. Feed and nutrient intake, faecal composition, and apparent protein digestibility by period and group

\begin{tabular}{|c|c|c|c|c|c|c|c|}
\hline \multirow{2}{*}{$\begin{array}{l}\text { Period }(\mathrm{P}) \dagger \\
\text { Group }(\mathrm{G}) \dagger\end{array}$} & \multicolumn{2}{|l|}{ Period 1} & \multicolumn{2}{|l|}{ Period 2} & \multicolumn{3}{|l|}{$P$-values } \\
\hline & Prot+ $(n=12)$ & Prot $-(n=11)$ & Prot+ $(n=12)$ & Prot $-(n=11)$ & G & $\mathrm{P}$ & $G \times P$ \\
\hline \multicolumn{8}{|l|}{ Intake $(\mathrm{kg} / \mathrm{d})$} \\
\hline Total dry matter & $20 \cdot 5$ & $20 \cdot 4$ & $20 \cdot 0$ & $22 \cdot 0$ & $0 \cdot 654$ & $0 \cdot 430$ & $0 \cdot 123$ \\
\hline TMR & $18 \cdot 1$ & $20 \cdot 4$ & $13 \cdot 7$ & $18 \cdot 0$ & $0 \cdot 039$ & $<0 \cdot 001$ & $0 \cdot 125$ \\
\hline Concentrates & $2 \cdot 43$ & $0 \cdot 0$ & $2 \cdot 43$ & $0 \cdot 0$ & - & - & - \\
\hline Extra hay & $0 \cdot 0$ & $0 \cdot 0$ & $3 \cdot 79$ & 3.95 & $0 \cdot 476$ & - & - \\
\hline Crude protein & $3 \cdot 25$ & $2 \cdot 85$ & $3 \cdot 21$ & $3 \cdot 08$ & $0 \cdot 222$ & $0 \cdot 304$ & $0 \cdot 149$ \\
\hline NEL, MJ & 117 & 112 & 115 & 123 & $0 \cdot 982$ & $0 \cdot 236$ & $0 \cdot 114$ \\
\hline \multicolumn{8}{|l|}{ Faecal composition (g/kg DM) } \\
\hline Crude protein & 169 & 169 & 176 & 170 & $0 \cdot 144$ & $0 \cdot 031$ & $0 \cdot 201$ \\
\hline Lignin & 127 & 129 & 125 & 126 & $0 \cdot 382$ & $0 \cdot 005$ & $0 \cdot 208$ \\
\hline Acid detergent fibre & 409 & 417 & 393 & 401 & $0 \cdot 002$ & $<0 \cdot 001$ & 0.946 \\
\hline Crude Ash & 135 & 137 & 119 & 117 & 0.963 & $<0 \cdot 001$ & $0 \cdot 448$ \\
\hline Apparent protein digestibility, $\%$ & $68 \cdot 6$ & $60 \cdot 7$ & $68 \cdot 0$ & $61 \cdot 0$ & $<0 \cdot 001$ & $0 \cdot 912$ & $0 \cdot 394$ \\
\hline
\end{tabular}

$\dagger$ Period 1: all roughages fed within TMR; Period 2: sequential feeding of hay and TMR.

†Prot+: receiving on average $2 \cdot 4 \mathrm{~kg} / \mathrm{d}$ individually fed concentrates; Prot-: receiving no individually fed concentrates.

Table 3. Milk and protein yields, milk composition, and protein efficiency by period and group

\begin{tabular}{|c|c|c|c|c|c|c|c|}
\hline \multirow{2}{*}{$\begin{array}{l}\text { Period }(\mathrm{P}) \dagger \\
\text { Group }(\mathrm{G}) \dagger\end{array}$} & \multicolumn{2}{|l|}{ Period 1} & \multicolumn{2}{|l|}{ Period 2} & \multicolumn{3}{|c|}{$P$-values } \\
\hline & Prot $+(n=12)$ & Prot- $(n=11)$ & Prot $+(n=12)$ & Prot $-(n=11)$ & G & $\mathrm{P}$ & $G \times P$ \\
\hline Milk yield (kg/d) & $25 \cdot 1$ & $22 \cdot 0$ & $23 \cdot 9$ & $20 \cdot 9$ & $0 \cdot 178$ & $0 \cdot 026$ & $0 \cdot 904$ \\
\hline Milk protein yield (g/d) & 770 & 684 & 758 & 684 & $0 \cdot 142$ & $0 \cdot 610$ & $0 \cdot 894$ \\
\hline Milk protein concentration (g/100 g) & $3 \cdot 09$ & $3 \cdot 20$ & $3 \cdot 22$ & $3 \cdot 34$ & $0 \cdot 430$ & $<0 \cdot 001$ & $0 \cdot 781$ \\
\hline Milk fat concentration $(\mathrm{g} / 100 \mathrm{~g})$ & $3 \cdot 81$ & $4 \cdot 14$ & $3 \cdot 91$ & $4 \cdot 12$ & $0 \cdot 119$ & $0 \cdot 516$ & $0 \cdot 805$ \\
\hline Milk urea concentration $(\mathrm{mg} / \mathrm{dl})$ & $16 \cdot 4$ & $14 \cdot 3$ & $19 \cdot 3$ & $15 \cdot 4$ & $0 \cdot 034$ & $0 \cdot 018$ & $0 \cdot 312$ \\
\hline Protein efficiency, g milk protein/g CP intake & $0 \cdot 235$ & $0 \cdot 235$ & $0 \cdot 222$ & $0 \cdot 215$ & $0 \cdot 855$ & $0 \cdot 046$ & $0 \cdot 664$ \\
\hline
\end{tabular}

$\dagger$ Period 1: all roughages fed within TMR; Period 2: sequential feeding of hay and TMR.

$\$$ Prot+: receiving on average $2 \cdot 4 \mathrm{~kg} / \mathrm{d}$ individually fed concentrates; Prot-: receiving no individually fed concentrates.

statistically affected by the group factor. Separate feeding of hay in the morning combined with the reduction of hay in the TMR (Period 2) did not influence total DM intake nor the intake of CP or NEL. Faecal concentrations of $\mathrm{CP}$, lignin and crude ash were the same in both groups; ADF was increased in group Prot- (Table 2). During Period 2, faecal concentrations of CP increased while those of lignin, ADF and crude ash decreased in both groups. The estimated apparent protein digestibility was clearly higher in Prot+ than in Prot-.

Milk and milk protein yield were numerically but not statistically lower in Prot-; milk yield decreased in both groups by $1 \mathrm{~kg} / \mathrm{d}$ on average from Period 1 to Period 2 (Table 3). Milk protein concentration was not affected by group but increased in all cows in Period 2. Milk fat was not affected by any factor. Milk urea was decreased in Protand increased in both groups during Period 2. Protein efficiency (the ratio of secreted milk protein to ingested protein) was identical in both groups but was reduced in Period 2.
Milk FA profile was shifted towards a higher proportion of saturated FA and a lower proportion of mono- (MUFA) and polyunsaturated FA (PUFA) in Prot- compared with Prot+ (Table 4). Within PUFA, mainly the proportions of linoleic acid $(18: 2 n-6)$ and of the conjugated linoleic acid (18:2 C9, t11) were reduced in Prot- (Fig. 1). Branched-chain FA (Table 4) and saturated odd-chain FA (Table 4) were higher in Prot- than in Prot+ across both periods.

\section{Discussion}

The core aim of the current study was to assess the effects of omitting individually fed protein concentrates on feed intake, milk and milk protein yields as well as indicators of feed protein efficiency in a moderate milk-type dairy cow breed in order to contribute controlled experimental data for low-concentrate dairy production systems. As a second factor, a manipulation of the roughage feeding system towards a sequential feeding of different roughage types was included in the study. The hypothesis behind 
Table 4. Milk fatty acid profiles (g/100 g fatty acid methyl ester) by period and group

\begin{tabular}{|c|c|c|c|c|c|c|c|}
\hline \multirow{2}{*}{$\begin{array}{l}\text { Period }(\mathrm{P}) \dagger \\
\text { Group }(\mathrm{G}) \dagger\end{array}$} & \multicolumn{2}{|l|}{ Period 1} & \multicolumn{2}{|l|}{ Period 2} & \multicolumn{3}{|c|}{$P$-values } \\
\hline & Prot $+(n=12)$ & Prot $-(n=11)$ & Prot+ $(n=12)$ & Prot $-(n=11)$ & G & $P$ & $G \times P$ \\
\hline Saturated FA & $64 \cdot 0$ & $67 \cdot 1$ & $65 \cdot 2$ & $69 \cdot 0$ & $0 \cdot 027$ & $0 \cdot 098$ & $0 \cdot 861$ \\
\hline Monounsaturated FA & $29 \cdot 5$ & $26 \cdot 7$ & $28 \cdot 0$ & $25 \cdot 2$ & $0 \cdot 044$ & $0 \cdot 110$ & 0.924 \\
\hline Polyunsaturated FA & $4 \cdot 44$ & $3 \cdot 82$ & $4 \cdot 75$ & $3 \cdot 64$ & $0 \cdot 001$ & $0 \cdot 345$ & $0 \cdot 017$ \\
\hline Branched-chain FA & $1 \cdot 59$ & $1 \cdot 76$ & $1 \cdot 52$ & $1 \cdot 65$ & $0 \cdot 003$ & $0 \cdot 008$ & $0 \cdot 691$ \\
\hline Saturated odd-chain FA & $2 \cdot 04$ & $2 \cdot 29$ & $2 \cdot 06$ & $2 \cdot 24$ & $0 \cdot 004$ & $0 \cdot 781$ & $0 \cdot 469$ \\
\hline
\end{tabular}

$\dagger$ Period 1: all roughages fed within TMR; Period 2: sequential feeding of hay and TMR.

\$Prot+: receiving on average $2.4 \mathrm{~kg} / \mathrm{d}$ individually fed concentrates; Prot-: receiving no individually fed concentrates.
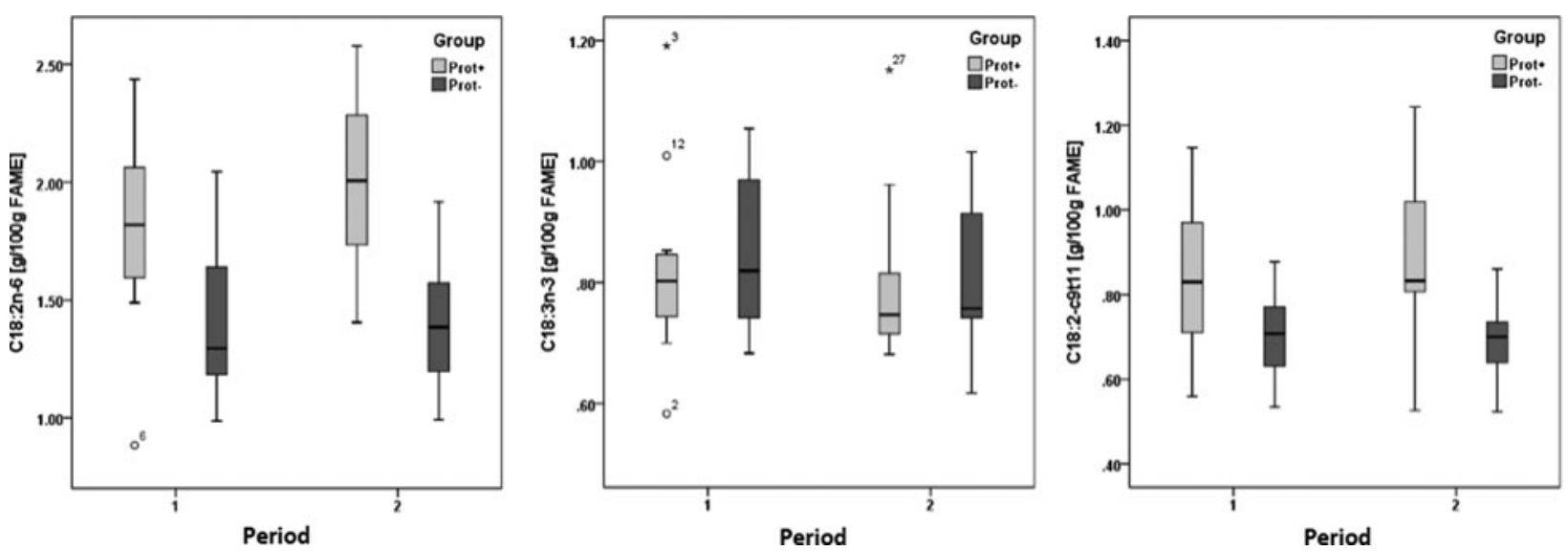

Fig. 1. Linoleic, $\alpha$-linolenic and conjugated linoleic acid [g/100 g FAME] in milk fat by group and period. Prot+: receiving on average $2 \cdot 4$ $\mathrm{kg} / \mathrm{d}$ individually fed concentrates; Prot-: receiving no individually fed concentrates. Period 1: all roughages fed within TMR; Period 2: sequential feeding of hay and TMR.

that factor was that cattle might increase their intake when more diversity in the feeding schedule is offered.

\section{Intake and protein efficiency as affected by dietary concentrates}

Group Prot- compensated the omission of individual concentrates by $100 \%$ in terms of DM with an increased roughage intake if compared with group Prot+. This is in line with other studies reporting substitution rates for concentrates which are even clearly higher than $100 \%$ (Berry et al. 2001; Lascano \& Heinrichs, 2011). By the increased roughage intake, the cows of group Prot- fully compensated for the NEL intake. The resulting similar intake of CP in both groups indicates that the effect of feeding protein concentrates on $\mathrm{CP}$ intake in the given herd with the given roughage quality was marginal. However, it has to be considered that the level of individually fed concentrates in the current study was generally low and the amount of omitted concentrates made up only about $10 \%$ of the whole diet (in terms of DM), while the soybean cake of the TMR remained in the diet of both groups.

The degradability of $\mathrm{CP}$ in roughages is lower than in soybean-based concentrates. This became obvious from the group effect on estimated apparent CP digestibility, which was large and to the advantage of the concentrate feeding. The values are closely comparable to data published by Røjen et al. (2008) and Cantalapiedra-Hijar et al. (2014) and show the expected effect of easily degradable $\mathrm{CP}$ in the concentrates.

Although it has to be noted that the protein efficiency was relatively low compared with literature values (Nousiainen et al. 2004; Cantalapiedra-Hijar et al. 2014), the maintained protein efficiency in Prot- was an important result of the current study. On the basis of apparently digestible CP, group Prot+ must have been much better supplied with degraded protein. However, milk and milk protein yields were not significantly affected by the group factor, although a numerical difference to the advantage of group Prot+ was visible in both periods with $P$-values $<0 \cdot 15$. The fact that protein efficiency (the ratio of milk protein to ingested $\mathrm{CP}$ ) was almost identical in both groups, despite the clearly lower apparent CP digestibility in group Prot-, showed a considerable metabolic capacity of the cows to increase the endogenous protein utilisation for milk production if digestible CP was reduced. Based on intake, protein efficiency was equal in both groups (Table 3). Based on the apparently digested $\mathrm{CP}$, the efficiency of the diet containing 
protein concentrates (Prot+) appeared to be even lower than that of the pure TMR and hay diets (Prot-). The finding of increased protein efficiency at low dietary protein supply is in line with earlier results (Nousiainen et al. 2004; Røjen et al. 2008; Kälber et al. 2012) and supports the hypothesis that dairy cows of a moderate milk-type are able to compensate reduced dietary $\mathrm{CP}$ concentrations to some degree (Knaus, 2009; Furger et al. 2013).

An important mechanism behind these results was probably lower ruminal ammonia production (Parker et al. 1995) and higher urea recycling into the rumen (Røjen et al. 2008). Changed rumen fermentation patterns were also indicated by the increased proportions of branchedand odd-chain FA (OBCFA) in the milk fat of group Prot- compared with Prot+, because these FA are to a large proportion of rumen microbial origin (Fievez et al. 2012). Increased proportions of OBCFA might indicate a rather low availability of easily soluble carbohydrates, higher rumen $\mathrm{pH}$ and lower propionate production (Fievez et al. 2012; Staerfl et al. 2013) which was also a consequence of the reduced concentrate supply. The effects show that analysis of these FA in milk has the potential to indicate metabolic responses to feeding situations although models for such an approach are still under development (Fievez et al. 2012).

The lower milk urea concentrations in group Prot- further indicate a lower metabolic demand for the cow to produce and excrete urea, which would be a metabolic advantage (Parker et al. 1995). Based on the lower milk urea concentration, which is highly indicative for $\mathrm{N}$ excretion with urine (Nousiainen et al. 2004; Spek et al. 2013), and the lower apparent $\mathrm{CP}$ digestibility, a shift of $\mathrm{N}$ excretion from urine to faeces can be assumed, which would be also of ecological advantage owing to less volatile $\mathrm{N}$-molecules in the manure (Weiss et al. 2009).

These outcomes are in favour of feeding concepts with considerably reduced protein concentrate supplementations, which would reduce demands for soybean in ruminant production, increase the utilisation of dietary CP from roughages, lower urinary $\mathrm{N}$ emissions, and could even be of economic advantage on the farm scale (Gazzarin et al. 2011).

\section{Effects of sequential feeding on intake and performance}

Based on studies showing increases in roughage intake when forbs with contrasting concentrations of plant secondary metabolites are fed in sequence (Villalba et al. 2004; Lyman et al. 2011), one hypothesis of the current study had been that sequential feeding could increase total feed intake by stimulating the animals' appetite via feed diversity (Villalba et al. 2010). This was not the case in the current experiment; even the numerical increase of intake in group Prot- was not statistically significant. The main reason may have been the very high feed intake cows showed already in Period 1, which could hardly be further increased. The decrease in milk yield during Period 2 might have been a consequence of ongoing lactation and increased reconstitution of body reserves. Otherwise the milk yield decrease is difficult to explain because NEL and CP intake remained on similar levels. The decrease of the branched-chain FA in both groups in Period 2 can however be interpreted as indicative of lower rumen $\mathrm{pH}$ and increased propionate and butyrate production (Fievez et al. 2012). This could have been the consequence of reducing the hay proportion in the TMR, which might have counterbalanced several effects of the sequential feed offer. However, there are too few literature data available on the effects of sequential feeding to draw clear conclusions. More research with different variations of sequences is required for this objective.

\section{Effects on milk quality}

The fact that neither milk protein nor milk fat concentrations differed between the groups indicates a similar endogenous nutrient supply of all cows. It suggests that on the basis of pricing-relevant milk constituents no disadvantage has to be expected from concentrate restrictions in a moderate dairy production system.

However the shift towards SFA in the milk FA profile of group Prot- has to be regarded as an unexpected disadvantage in terms of the nutritional value. Roughage-rich diets are repeatedly described as promoting rather high proportions of PUFA in milk fat (Khiaosa-ard et al. 2010; Shingfield et al. 2013). The main PUFA, which occurred in reduced proportions in milk fat of Prot-, was 18:2 n-6 (linoleic acid) and its ruminal derivative 18:2 c9,t11 (CLA). This was probably due to the lack of soybean, which is a typical source of linoleic acid. Linolenic acid, the important precursor of $n-3$ FA in human metabolism (Barceló-Coblijn \& Murphy, 2009) was not affected by the feeding regimes. This means that the $\mathrm{n} 3 / \mathrm{n}-6$ ratio was not adversely changed, but rather increased which can be considered a positive effect on the nutritional value of the milk fat.

In conclusion, the current study showed that in a moderate organic dairy production system with generally low concentrate levels, the omission of protein-rich supplements may lead to increased roughage intake, partly enabling the cow to maintain the amount of CP consumption. Despite lower apparent CP digestibility, the ratio of milk protein to ingested CP was maintained in group Prot - indicating a high potential to increase the ruminal $\mathrm{N}$ efficiency, probably by urea recycling, if the dietary CP supply is reduced. The sequential offer of varying roughages did not lead to considerable effects in intake and efficiency. Changes in milk quality were small and not relevant for human nutrition and for the current European pricing systems.

The authors gratefully acknowledge the support provided by the Swiss Federal Office of Agriculture, Berne, and by Bio Suisse, Basel. 


\section{References}

Agroscope 2013 Fütterungsempfehlungen und Nährwerttabellen für Wiederkäuer. [Feeding recommendations for ruminants] http://www. agroscope.admin.ch/futtermitteldatenbank/04834/index.html Accessed January 15, 2015

Barceló-Coblijn G \& Murphy EJ 2009 Alpha-linolenic acid and its conversion to longer chain $\mathrm{n} 3$ fatty acids: benefits for human health and a role in maintaining tissue n3 fatty acid levels. Progress in Lipid Research 48 355-374

Berry NR, Sutter F, Bruckmaier RM, Blum JW \& Kreuzer M 2001 Limitations of high Alpine grazing conditions for early-lactation cows: effects of energy and protein supplementation. Animal Science 73 149-162

Cantalapiedra-Hijar G, Peyraud JL, Lemosquet S, Molina-Alcaide E, Boudra H, Nozière P \& Ortigues-Marty I 2014 Dietary carbohydrate composition modifies the milk $\mathrm{N}$ efficiency in late lactation cows fed low crude protein diets. Animal 8 275-285

Cassidy ES, West PC, Gerber JS \& Foley JA 2013 Redefining agricultural yields: from tonnes to people nourished per hectare. Environmental Research Letters 8034015

Clauss M, Hume ID \& Hummel J 2010 Evolutionary adaptations of ruminants and their potential relevance for modern production systems. Animal 4 979-992

CVAS (Cumberland Valley Analytical Services) 2008 Near infrered spectroscopy for forage and feed testing. http://www.foragelab.com/Media/ nirs_white_paper.pdf Accessed January 15, 2015

Ertl P, Knaus W \& Steinwidder A 2014 Comparison of zero concentrate supplementation with different quantities of concentrates in terms of production, animal health, and profitability of organic dairy farms in Austria. Organic Agriculture 4 233-242

Fievez V, Colman E, Castro-Montoya JM, Stefanov I \& Vlaeminck B 2012 Milk odd- and branched-chain fatty acids as biomarkers of rumen function-An update. Animal Feed Science and Technology 172 51-65

Furger M, Kunz P, Schaffner M, Schwarzenberger M, Bürgisser M, Peer G \& Brandenburger C 2013 Hochleistungskühe füttern: mit oder ohne Kraftfutter? [Feeding high-yielding cows: with or without concentrates?]. ETH-Schriftenreihe zur Tierernährung 36 11-25

Gazzarin C, Frey HJ, Petermann R \& Höltschi M 2011 Weide- oder Stallfütterung - was ist wirtschaftlicher? [Pasture feeding or cowshed feeding - which is more economical?]. Agrarforschung Schweiz 2 418-423

Gross J, van Dorland HA, Bruckmaier RM \& Schwarz FJ 2011 Performance and metabolic profile of dairy cows during a lactational and deliberately induced negative energy balance with subsequent realimentation. Journal of Dairy Science 94 1820-1830

Horn M, Steinwidder A, Pfister R, Gasteiner J, Vestergaard M, Larsen T \& Zollitsch W 2014 Do different cow types respond differently to a reduction of concentrate supplementation in an Alpine low-input dairy system? Livestock Science $17072-83$

Ivemeyer S, Walkenhorst M, Holinger M, Maeschli A, Klocke P, Spengler Neff A, Staehli P, Krieger M \& Notz C 2014 Changes in herd health, fertility and production under roughage based feeding conditions with reduced concentrate input in Swiss organic dairy herds. Livestock Science 168 159-167

Kälber T, Kreuzer M \& Leiber F 2012 Silages containing buckwheat and chicory: quality, digestibility and nitrogen utilisation by lactating cows. Archives of Animal Nutrition 66 50-65

Khiaosa-ard R, Klevenhusen F, Soliva CR, Kreuzer M \& Leiber F 2010 Transfer of linoleic and linolenic acid from feed to milk in cows fed isoenergetic diets differing in proportion and origin of concentrates and roughages. Journal of Dairy Research 77 331-336
Knaus W 2009 Dairy cows trapped between performance demands and adaptability. Journal of the Science of Food and Agriculture 89 1107-1114

Lascano GJ \& Heinrichs AJ 2011 Effects of feeding different levels of dietary fiber through the addition of corn stover on nutrient utilization of dairy heifers precision-fed high and low concentrate diets. Journal of Dairy Science 94 3025-3036

Leiber F 2014 Resigning protein concentrates in dairy cattle nutrition: a problem or a chance?. Organic Agriculture 4 269-273

Lyman TD, Provenza FD, Villalba JJ \& Wiedmeier RD 2011 Cattle preferences differ when endophyte-infected tall fescue, birdsfoot trefoil, and alfalfa are grazed in different sequences. Journal of Animal Science $\mathbf{8 9}$ 1131-1137

Macleod GK, Colucci PE, Moore AD, Grieve DG \& Lewis N 1994 The effects of feeding frequency of concentrates and feeding sequence of hay on eating behaviour, ruminal environment and milk production in dairy cows. Canadian Journal of Animal Science 74 103-113

Nousiainen J, Shingfield KJ \& Huhtanen P 2004 Evaluation of milk urea nitrogen as a diagnostic of protein feeding. Journal of Dairy Science $\mathbf{8 7}$ 386-398

O'Mara FP 2012 The role of grasslands in food security and climate change. Annals of Botany 110 1263-1270

Parker DS, Lomax MA, Seal CJ \& Wilton JC 1995 Metabolic implications of ammonia production in the ruminant. Proceedings of the Nutrition Society 54 549-563

Pelletier N \& Tyedmers P 2010 Forecasting potential global environmental costs of livestock production 2000-2050. PNAS 107 18371-18374

Røjen BA, Lund P \& Kristensen NB 2008 Urea and short-chain fatty acids metabolism in Holstein cows fed a low-nitrogen grass-based diet. Animal 2 500-513

Shingfield KJ, Bonnet M \& Scollan ND 2013 Recent developments in altering the fatty acid composition of ruminant-derived foods. Animal 7(s1) $132-162$

Spek JW, Dijkstra J, van Duinkerken G, Hendriks WH \& Bannink A 2013 Prediction of urinary nitrogen and urinary urea nitrogen excretion by lactating dairy cattle in northwestern Europe and North America: a metaanalysis. Journal of Dairy Science 96 4310-4322

Staerfl SM, Amelchanka SL, Kälber T, Soliva CR, Kreuzer M \& Zeitz JO 2012 Effect of feeding dried high-sugar ryegrass ('AberMagic') on methane and urinary nitrogen emissions of primiparous cows. Livestock Science 150 293-301

Staerfl SM, Zeitz JO, Amelchanka SL, Kälber T, Kreuzer M \& Leiber F 2013 Comparison of the milk fatty acid composition from dairy cows fed highsugar ryegrass, low-sugar ryegrass, or maize. Dairy Science \& Technology 93 201-210

Suter B, Grob K \& Pacciarelli B 1997 Determination of fat content and fatty acid composition through 1-min transesterification in the food sample; principles. Zeitschrift für Lebensmittel-Untersuchung und-Forschung A 204 252-258

Villalba JJ, Provenza FD \& Han G 2004 Experience influences diet mixing by herbivores: implications for plant biochemical diversity. Oikos $\mathbf{1 0 7}$ 100-109

Villalba JJ, Provenza FD \& Manteca X 2010 Links between ruminants' food preference and their welfare. Animal 4 1240-1247

Weiss WP, Willet LB, St-Pierre NR, Borger DC, McKelvey TR \& Wyatt DJ 2009 Varying forage type, metabolizable protein concentration, and carbohydrate source affects manure excretion, manure ammonia, and nitrogen metabolism of dairy cows. Journal of Dairy Science 92 5607-5619

Von Witzke H, Noleppa S \& Zhirkova I 2011 Fleisch frisst Land. [Meat eats land]. Berlin, Germany: WWF. 73 pp

Wilkinson JM 2011 Re-defining efficiency of feed use by livestock. Animal 5 1014-1022 